\title{
Rapid dissemination of Francisella tularensis and the effect of route of infection
}

\author{
Sandra S Ojeda ${ }^{\dagger 1}$, Zheng J Wang ${ }^{\dagger 2}$, Chris A Mares ${ }^{1}$, Tingtung A Chang ${ }^{3}$, \\ Qun Li ${ }^{5}$, Elizabeth G Morris ${ }^{5}$, Paul A Jerabek ${ }^{4}$ and Judy M Teale*1,5
}

\begin{abstract}
Address: ${ }^{1}$ Department of Microbiology and Immunology, University of Texas Health Science Center at San Antonio, 7703 Floyd Curl Dr., San Antonio, TX, 78229, USA, ${ }^{2}$ MPI Research, 54943 North Main Street, Mattawan, MI, 49071, USA, ${ }^{3}$ Department of Radiology, University of Texas Health Science Center at San Antonio, 7703 Floyd Curl Dr., San Antonio, TX, 78229, USA, ${ }^{4}$ Research Imaging Center, University of Texas Health Science Center at San Antonio, 7703 Floyd Curl Dr., San Antonio, TX, 78229, USA and ${ }^{5}$ Department of Biology, University of Texas at San Antonio, One UTSA Circle San Antonio, TX, 78249, USA

Email: Sandra S Ojeda - ojeda@uthscsa.edu; Zheng J Wang - zheng.wang@mpiresearch.com; Chris A Mares - mares@uthscsa.edu; Tingtung A Chang - changt2@uthscsa.edu; Qun Li - qun.li@utsa.edu; Elizabeth G Morris - Elizabeth.Morris@utsa.edu; Paul A Jerabek - jerabek@uthscsa.edu; Judy M Teale* - judy.teale@utsa.edu

* Corresponding author †Equal contributors
\end{abstract}

Published: 9 December 2008

BMC Microbiology 2008, 8:215
Received: 21 May 2008

Accepted: 9 December 2008

This article is available from: http://www.biomedcentral.com/I47|-2/80/8/215

(C) 2008 Ojeda et al; licensee BioMed Central Ltd.

This is an Open Access article distributed under the terms of the Creative Commons Attribution License (http://creativecommons.org/licenses/by/2.0), which permits unrestricted use, distribution, and reproduction in any medium, provided the original work is properly cited.

\begin{abstract}
Background: Francisella tularensis subsp. tularensis is classified as a Category A bioweapon that is capable of establishing a lethal infection in humans upon inhalation of very few organisms. However, the virulence mechanisms of this organism are not well characterized. Francisella tularensis subsp. novicida, which is an equally virulent subspecies in mice, was used in concert with a microPET scanner to better understand its temporal dissemination in vivo upon intranasal infection and how such dissemination compares with other routes of infection. Adult mice were inoculated intranasally with $F$. tularensis subsp. novicida radiolabeled with ${ }^{64} \mathrm{Cu}$ and imaged by microPET at 0.25 , 2 and 20 hours post-infection.
\end{abstract}

Results: ${ }^{64} \mathrm{Cu}$ labeled $F$. tularensis subsp. novicida administered intranasally or intratracheally were visualized in the respiratory tract and stomach at 0.25 hours post infection. By 20 hours, there was significant tropism to the lung compared with other tissues. In contrast, the images of radiolabeled F. tularensis subsp. novicida when administered intragastrically, intradermally, intraperitoneally and intravenouslly were more generally limited to the gastrointestinal system, site of inoculation, liver and spleen respectively. MicroPET images correlated with the biodistribution of isotope and bacterial burdens in analyzed tissues.

Conclusion: Our findings suggest that Francisella has a differential tissue tropism depending on the route of entry and that the virulence of Francisella by the pulmonary route is associated with a rapid bacteremia and an early preferential tropism to the lung. In addition, the use of the microPET device allowed us to identify the cecum as a novel site of colonization of Francisella tularensis subsp. novicida in mice. 

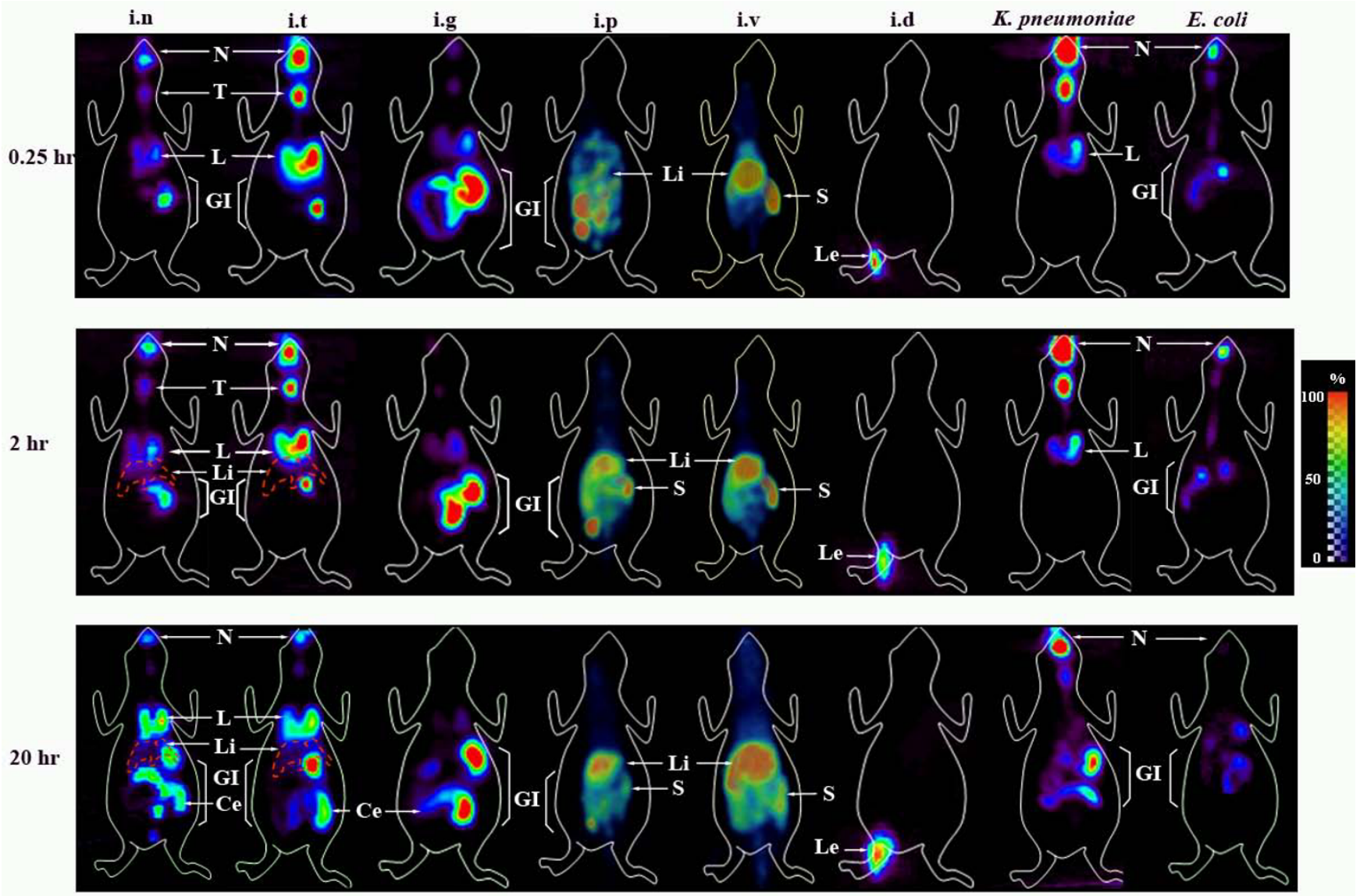

\section{Figure I}

MicroPET imaging of bacterial infection of mice. Two-dimensional images of representative mice (ventral view) are depicted in the figure. MicroPET images were recorded over time from mice infected with either ${ }^{64} \mathrm{Cu}$ labeled $F$. tularensis subsp. novicida, ${ }^{64} \mathrm{Cu}$ labeled $K$. pneumoniae or ${ }^{64} \mathrm{Cu}$ labeled $E$. coli. Mice were infected i.n, i.t, i.g, i.p, i.v and i.d with $F$. tularensis subsp. novicida $\left(2 \times 10^{9} \mathrm{CFU} / 20 \mu \mathrm{l}\right)$ and i.n with $K$. pneumoniae and $E$. coli using the same infection dose. Images were obtained at $0.25 \mathrm{hrs}, 2 \mathrm{hrs}$ and $20 \mathrm{hrs}$ p.i. The red punctuated line represents the liver. The color scale on the right hand side of the figure is a linear scale that indicates percentage with red indicating $100 \%$ of signal and purple 0-10\% or the lowest amount detected by imaging. Abbreviations: N: Nasal cavity, T: Trachea, L: Lung, Gl: Gastrointestinal Tract, Li: Liver, S: Spleen, Le: Leg, Ce: Cecum.

\section{Background}

Francisella tularensis is a facultative intracellular pathogen that is the causative agent of tularemia. Francisella has a broad host range as it is able to infect amoeba, arthropods, rodents and higher mammalian species [1-4]. The primary replication site in humans appears to be the macrophage although other cell types have been implicated [5-7]. Infection is established through contact with infected tissues, arthropod bites, inhalation or ingestion which can lead to various clinical manifestations $[3,8]$. The route of infection is a key determining factor in the pathogenesis of this organism, and inhalation is the most dangerous $[3,9,10]$. There are two subspecies of F. tularensis, that are capable of causing disease in humans $[9,10]$. F. tularensis (type A) is primarily found in North America. It is the most virulent strain and is capable of causing dis- ease with as few as 10 organisms. The highly virulent nature of this microorganism combined with its ability to be aerosolized has led to its designation as a Category A biological warfare agent by the CDC $[3,11]$. F. tularensis subsp. holarctica (type B) is less virulent than type A, but it is found more readily across the northern hemisphere. Type $\mathrm{B}$ is also the parent strain from which the important F. tularensis LVS was derived [12]. F. tularensis subsp. novicida is another important laboratory strain as it remains highly virulent in mice but can be studied in a BSL-2 facility allowing access to new technology such as positron emission tomography (PET).

PET has been utilized to detect cells, proteins and gene expression in humans in vivo [13-15]. In humans, PET has been used as a research tool for whole body imaging and 


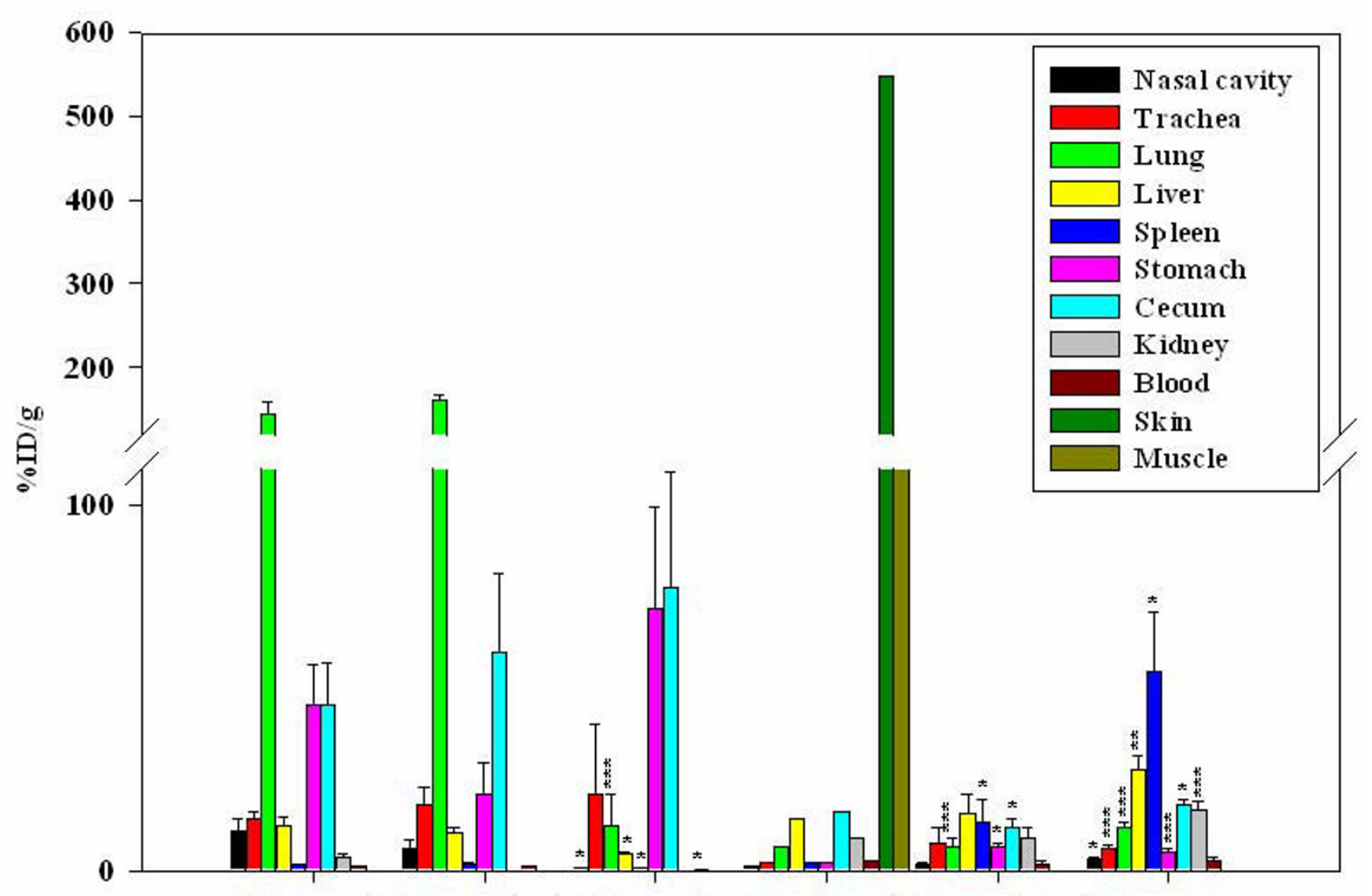

Intranasal Intratracheal Intragastric Intradermal Intraperitoneal Intravenous

\section{Figure 2}

Biodistribution of ${ }^{64} \mathrm{Cu}$ labeled $\boldsymbol{F}$. tularensis subsp. novicida. In order to confirm the observations from the microPET images the distribution of labeled bacteria was further analyzed by measuring the amount of radioactivity present in individual tissues at $20 \mathrm{hrs}$ p.i. The data represent an average of 3-9 mice per route of infection and are expressed as \% ID/g of tissue. The data obtained for each of the tissues sampled following i.n infection was compared statistically to the same tissue when inoculated by the i.g, i.p and i.v routes by using a two tail Student's t-test [e.g. lung (i.n) to lung (i.g)]. $*=p<0.05$, $* *=p<0.0$ I and $* * *=p<0.005$. Data obtained following the i.d route was not included for the statistical analyses because it corresponded to just two biological replicates. The break in the scale was done between II 0 and I 20.

is now transitioning into diagnostic tools in oncology and in the detection of Alzheimer's disease [16]. Recent advances in microPET design have led to the production of scanners that are capable of imaging rodents with high resolution $[13,17,18]$. Advancements in labeling techniques as well as different substrates $[19,20]$ have allowed for cell trafficking and distribution studies $[15,21,22]$ as well as for tracing bacteria in infections $[23,24]$ and for tumor detection [25]. The major advantage to utilizing microPET imaging is that it is a non-invasive process with high sensitivity that allows the investigator to perform longitudinal studies on one animal rather than sacrificing several animals at various time points [16].
We have exploited the capability of small animal microPET coupled with radionuclide labeling to help us investigate the spatial and temporal biodistribution of $F$. tularensis subsp. novicida in vivo. Mice were infected with ${ }^{64} \mathrm{Cu}$-pyruvaldehyde-bis( $\mathrm{N}^{4}$-methylthiosemicarbazone) ([ $\left.{ }^{64} \mathrm{Cu}\right]$ PTSM) labeled F. tularensis subsp. novicida by different inoculation routes including intranasal, intratracheal, intragastric, intraperitoneal, intravenous and intradermal. The trafficking of labeled F. tularensis subsp. novicida was compared with the control organisms E. coli and $K$. pneumoniae using both microPET analysis and radionuclide biodistribution analyses. Our results indicate that F. tularensis subsp. novicida has a differential tissue 


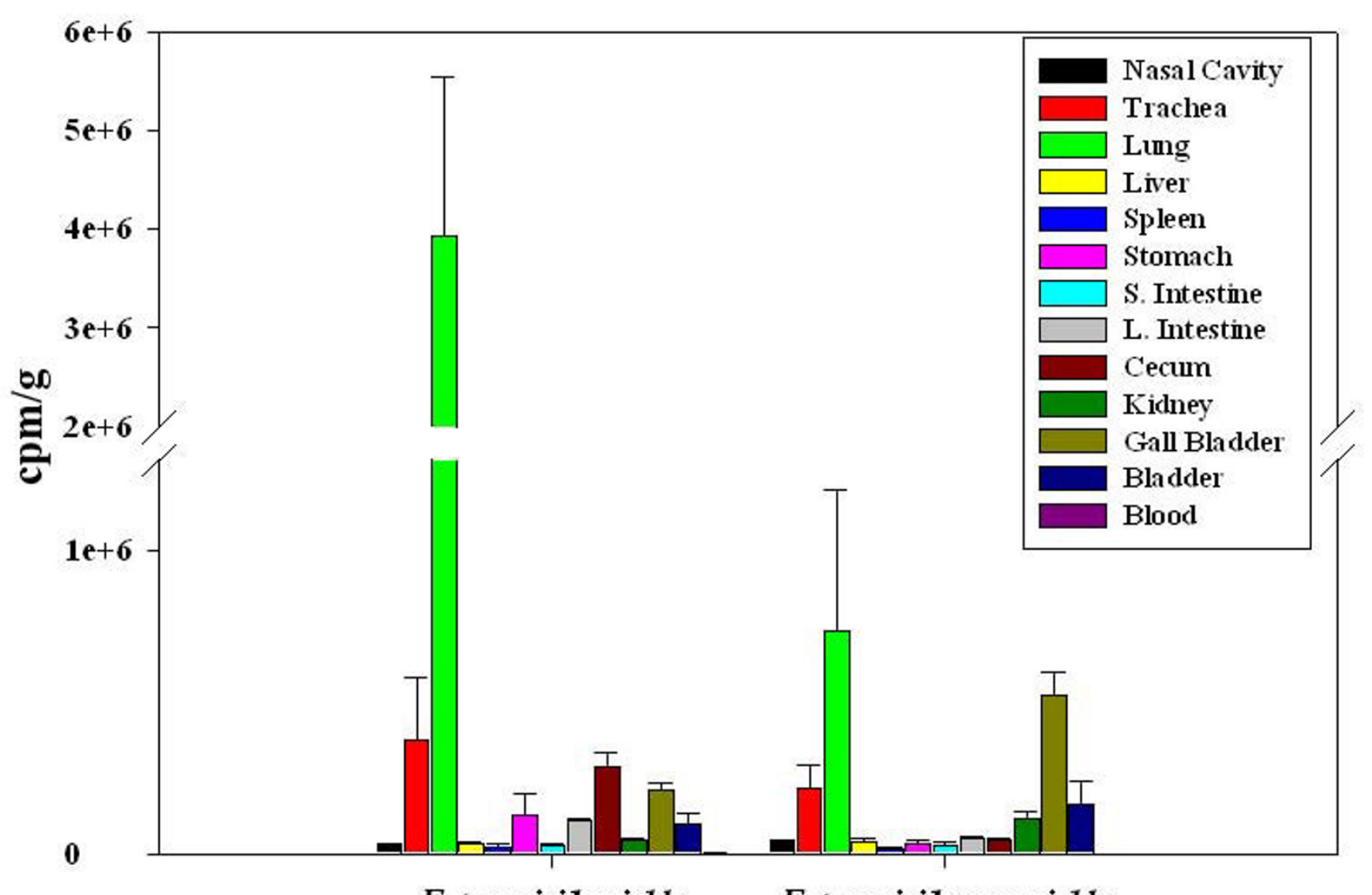

Figure 3

Biodistribution of viable vs. non viable ${ }^{35} \mathrm{~S}$ labeled bacteria. As a mode to compare the localization of labeled bacteria, metabolic labeling was performed for F. tularensis subsp. novicida. The data represent an average of 3 mice per treatment and are expressed as cpm/g. Viable (unfixed) labeled F. tularensis subsp. novicida is found mainly in the lungs while there was an increase in non-viable (fixed) organisms localizing primarily to the gall bladder.

tropism depending on the route of entry and that when given by the intranasal or intratracheal route has a propensity to colonize the respiratory tract rapidly after infection tending to disseminate to other target organs within a very short period of time.

\section{Results}

\section{In vivo trafficking of bacteria in real time}

F. tularensis subsp. novicida, a highly virulent strain in mice, was directly labeled with ${ }^{64} \mathrm{Cu}$-PTSM so that its route of dissemination and anatomical distribution after inoculation could be traced by repetitive microPET imaging of live animals. C57BL/ 6 mice were infected i.n with 2 $\times 10^{9} \mathrm{CFU} / 20-25 \mu \mathrm{l}$ of bacteria and accumulated positron emission measured for a 15 min period immediately after inoculation (labeled $0.25 \mathrm{hr}$ ), 2 hrs and $20 \mathrm{hrs}$ post-infection (p.i) by using a microPET scanner. Still images are shown in Fig. 1, and images that can be rotated $360^{\circ}$ can be found in Additional File 1. Surprisingly, by $0.25 \mathrm{hr}$ (15 min) p.i we observed radiolabel not only in the nasal cavity at the site of inoculation but also in the lung and even in the digestive tract (Fig. 1). The inoculum volume of 20$25 \mu \mathrm{l}$ has been shown to avoid introduction into the lung $[26,27]$, but the rapid spread was found repeatedly in multiple animals. At 2 hrs p.i labeled organisms tracked to the same organs but the amount of ${ }^{64} \mathrm{Cu}$ detected by the microPET increased in the lungs as well as the GI tract suggesting an increase in the number of bacteria present in these organs. Interestingly, the cecum was usually a hot spot for labeled organisms. The images obtained $20 \mathrm{hrs}$ post-infection indicated a decrease in label intensity present in the nasal cavity, an additional increase in the lung and further spread through the GI tract (Fig. 1). The recent acquisition of a FLEX Pre-Clinical Platform allowed 


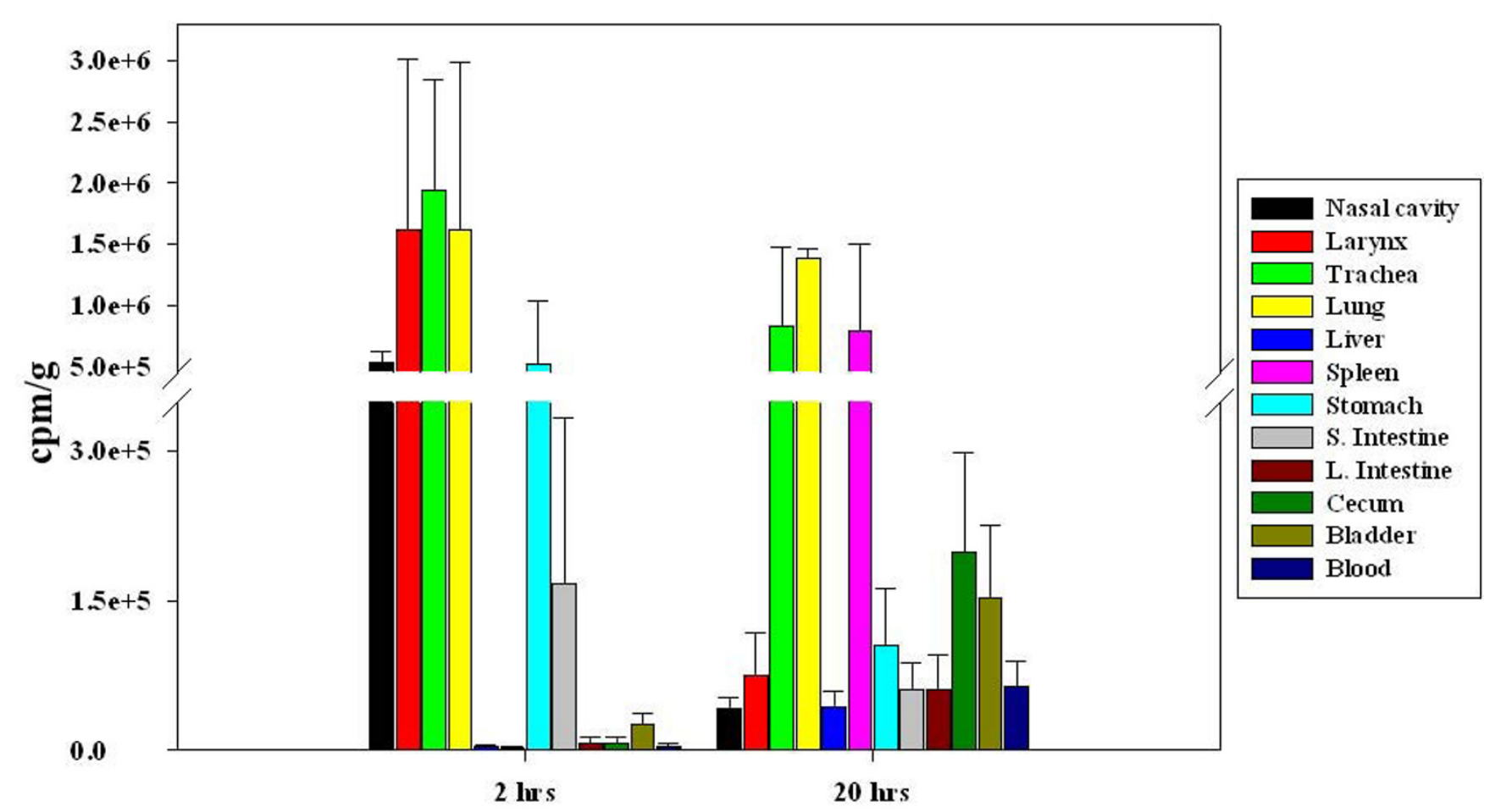

\section{Figure 4}

Presence of $\boldsymbol{F}$. tularensis subsp. novicida in the $\mathbf{G I}$ tract at early time points. As a way to discard the possibility of swallowing of the inoculum during i.n and i.t infections we tested an endotracheal entubation of mice to directly deliver ${ }^{35 S}$ labeled $F$. tularensis subsp. novicida into the trachea. Data shown represent an average of 3-4 mice and is given as cpm/g. Our biodistribution results showed that after 2 hrs p.i the majority of the labeled organisms were present in the lung and trachea; furthermore, a high proportion of labeled organisms were present in the stomach. In addition, after 20 hrs p.i the highest amount of labeled bacteria was present in the lung and further disseminated to other tissues including the cecum.

us to obtain an X-ray computed tomography (CT) image of the skeletal structure of mice that had been previously infected by the i.p and i.v routes prior to acquire the microPET images (Additional Files 2 and 3). The advantage is that a fused image of the skeletal structure with the microPET image is obtained and in this way a better indication of the localization of the labeled organisms in vivo is possible. Additional Files 1, 2 and 3 show fused images obtained at 0.25 hrs for i.n. i.p and i.v inoculations. To further analyze isotope distribution, inoculated animals were sacrificed, and several organs harvested to measure the amount of radioisotope using an automatic well-type $\gamma$ counter. The combined ex-vivo data obtained from several experiments are expressed as \% input dose/g of tissue (\%ID/g) (Fig. 2). The results obtained with F. tularensis subsp. novicida i.n infected animals correlate with the microPET analyses indicating the highest concentration of ${ }^{64} \mathrm{Cu}$ in the lung, stomach and GI tract. Importantly, essentially all organs and tissues tested contained radioactivity suggesting widespread dissemination of Francisella by 20 hrs p.i.
To ensure that the radioactivity was indeed a measure of viable labeled bacteria, four tissues were analyzed for CFU/g of tissue at $20 \mathrm{hrs} \mathrm{p.i} \mathrm{(Additional} \mathrm{File} \mathrm{6).} \mathrm{Due} \mathrm{to}$ normal flora, intestinal tissues were not analyzed but Francisella is also known to colonize the liver. Consistent with radioisotope measurements in vivo and ex vivo, the lungs contained the highest bacterial burden with greater than 4-5 logs of bacteria/g of tissue compared with the bladder. The liver was also several logs lower reflective of a \%ID/g that was visualized by microPET at 20 hrs with a blue/purple color indicative of lower levels of radioisotope/g. Taken together; these results indicate that levels of radioisotope reflect numbers of viable organisms. Because of the rapidity of dissemination, the presence of viable organisms in the blood was also tested and found to be present (Additional File 6).

\section{Viable vs. non-viable bacteria}

To determine the effect of viability on bacterial trafficking, F. tularensis subsp. novicida metabolically labeled with ${ }^{35} \mathrm{~S}$ L-methionine and ${ }^{35}$ S-L-cysteine was taken to a titer of $2 \times$ 


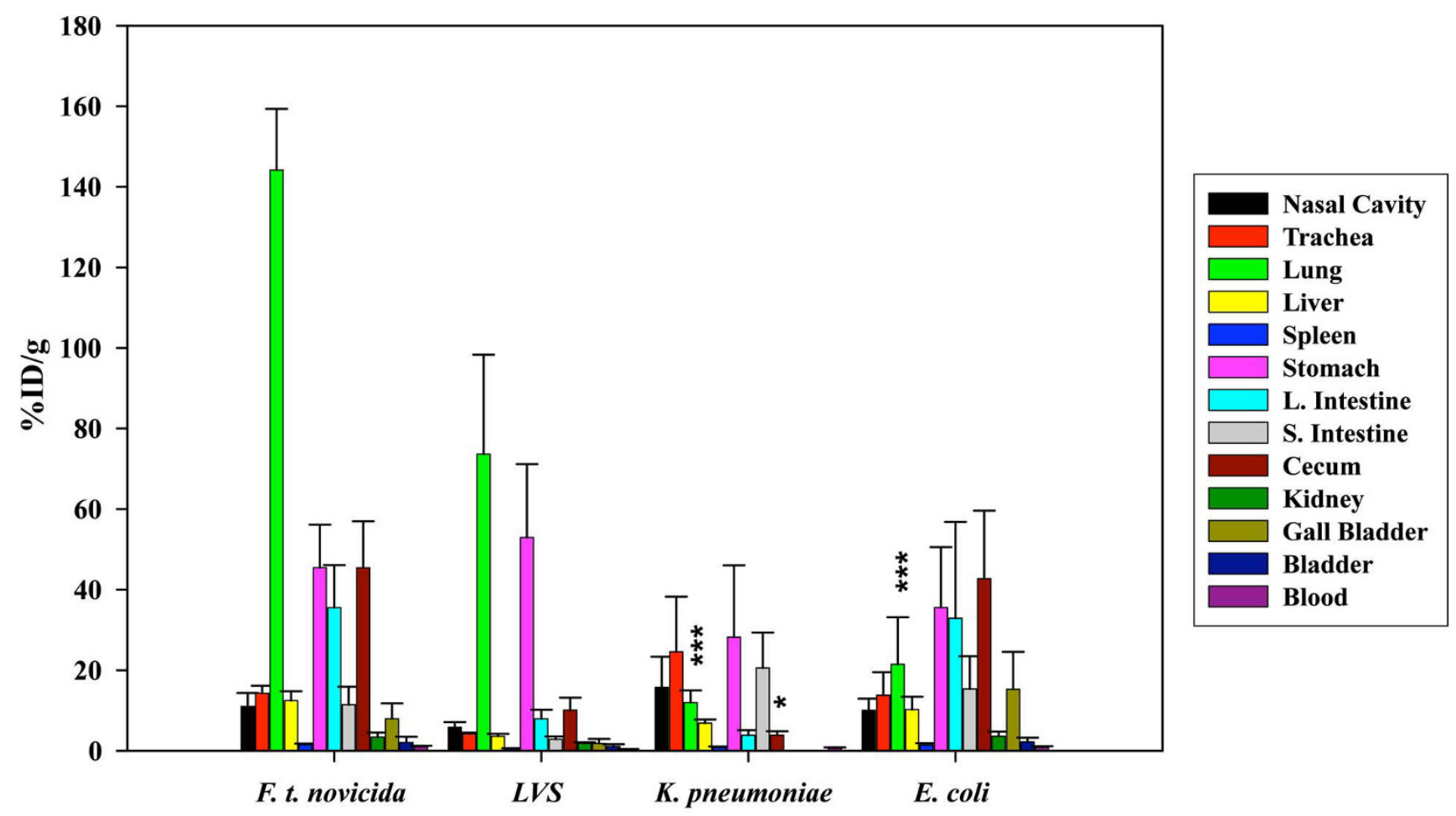

Figure 5

Biodistribution of ${ }^{64} \mathrm{Cu}$ labeled bacteria. The distribution of ${ }^{64} \mathrm{Cu}$ labeled $\mathrm{F}$. tularensis subsp. novicida was compared to ${ }^{64} \mathrm{Cu}$ labeled $K$. pneumoniae, ${ }^{64} \mathrm{Cu}$ labeled $\mathrm{E}$. coli and ${ }^{64} \mathrm{Cu}$ labeled LVS in each tissue at $20 \mathrm{hrs}$ pi. The data represent an average of $3-9$ mice per infection and are given as \%ID/g of tissue. The data obtained for each of the tissues sampled $20 \mathrm{hrs}$ p.i from mice infected with $F$. tularensis subsp. novicida was compared statistically to the same tissue when inoculated with ${ }^{64} \mathrm{Cu}$ labeled K. pneumoniae and E. coli at 20 hrs p.i by using a two tail Student's t-test [e.g. lung (i.n) to lung (i.g)]. $*=p<0.05$, $* *=p<0.0$ I and $* * *=p<0.005$.

$10^{9}$ and then fixed in $4 \%$ paraformaldehyde. Subsequently labeled bacteria were administered to mice i.n, and the accumulation of label in various tissues was compared with that of non-fixed, viable organisms. The data are expressed as counts per minute/g (cpm/g) (Fig. 3) and indicate that the bulk of the label was present in the lungs at $20 \mathrm{hrs}$ p.i when viable (unfixed) organisms were used but more evenly distributed among the tissues analyzed when non-viable (fixed) organisms were used. In addition, use of non-viable organisms resulted in a significant increase in label in the gall bladder compared with viable organisms.

Several of the tissues from mice receiving viable organisms were also tested for $\mathrm{CFU} / \mathrm{g}$ of tissue (data not shown). Similar to the results obtained with ${ }^{64} \mathrm{Cu}$ labeling, the lung exhibited the highest bacterial burden from all the organs tested. Viable bacteria were also detected in the liver, spleen, superficial lymph nodes, Peyer's patches, and blood correlating with the presence of isotope but at lower levels in all of these tissues.

\section{Effect of bacterial route of entry}

Francisella tularensis can establish infection in the host when entering through different routes. The severity of the disease differs according to the route of infection and the inhalation route is known to be the most dangerous form. Due to these facts and to the results obtained in our microPET studies following i.n infection, our laboratory decided to study F. tularensis subsp. novicida in vivo distribution following other routes of infection by which Francisella is also known to enter the host and cause disease. First, we included an important control for the i.n infection. When bacteria were administered i.n in just $20-25$ $\mu \mathrm{l}$, labeled organisms appeared in the GI tract by $0.25 \mathrm{hr}$ (15 min) including the stomach, therefore it was important to control for swallowing. So in a set of experiments, mice were inoculated with the same dose of organisms $(2$ $\times 10^{9} \mathrm{CFU}$ ) but by the i.t route (Fig. 1 and Additional File 4 left). The i.t inoculation was done by administering the bacterial dose at the back of the throat while holding the tongue in an extended position thus preventing swallowing as described previously $[28,29]$. This explains label in 


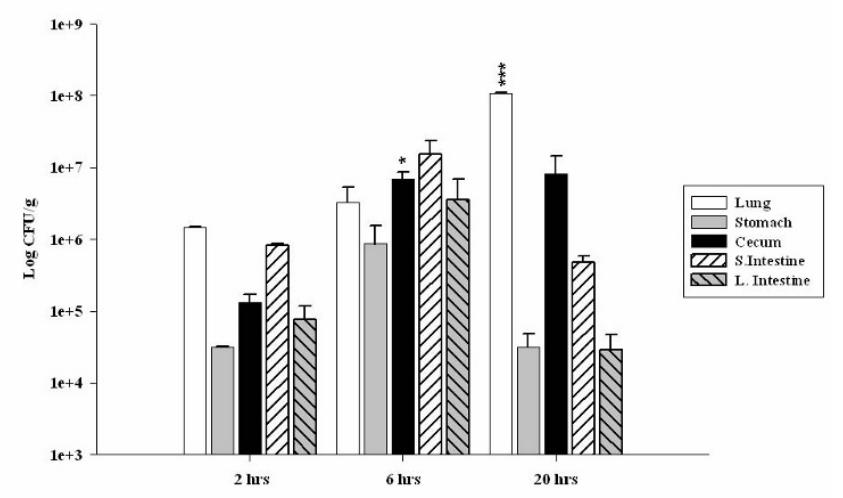

Figure 6

Colonization of various tissues by $\boldsymbol{F}$. tularensis subsp. novicida. In order to determine the presence of $F$. tularensis subsp. novicida in the GI tract after i.n infection a Rif ${ }^{+}$resistant strain was generated. Data represent an average of 3 mice per time point and are given as Log CFU/g of tissue. Lung, stomach, cecum, small intestine and large intestine were harvested at $2 \mathrm{hrs}, 6 \mathrm{hrs}$ and $20 \mathrm{hrs}$ p.i and CFU were determined. The data obtained for each of the tissues sampled 2 hrs p.i was compared statistically by using a two tail Student's t-test to the data obtained $6 \mathrm{hrs}$ and $20 \mathrm{hrs}$ p.i. $*=$ $\mathrm{p}<0.05$, ** $=\mathrm{p}<0.0 \mathrm{I}$ and $* * *=\mathrm{p}<0.005$.

the head area at the site of inoculation. The results obtained were similar in that labeled organisms could be observed by microPET in the gastrointestinal tract by 0.25 hr (15 min). Similar to the i.n route, by 20 hrs the majority of label appeared in the lung and GI tract including the cecum although the relative amount of label in the lung was higher, especially at 0.25 and 2 hrs p.i. The results observed by microPET were confirmed by determining the biodistribution of label ex vivo in various tissues and the data represent an average of 3 animals after imaging (Fig. 2 ). To further discard the possibility of swallowing of the inoculum during i.n and i.t infections we decided to test an endotreacheal intubation of the mice to directly deliver ${ }^{35} \mathrm{~S}$ labeled $F$. tularensis subsp. novicida into the trachea. Our biodistribution data shows that after 2 hrs p.i the majority of the labeled bacteria are localized in the trachea and lung; interestingly, there is also a high proportion of labeled F. tularensis subsp. novicida present in the stomach (Fig. 4). In addition, after 20 hrs p.i the biodistribution data shows that the highest concentration of labeled bacteria appeared to be present in the lung and trachea followed by the spleen; furthermore, labeled F. tularensis subsp. novicida appeared to be present in the cecum as well (Fig. 4). These results correlate with the ones obtained by microPET, early after infection F. tularensis subsp. novicida localizes in the lung and stomach, while after 20 hrs p.i the bacterium remains in the lung and further disseminates to other tissues including the cecum.

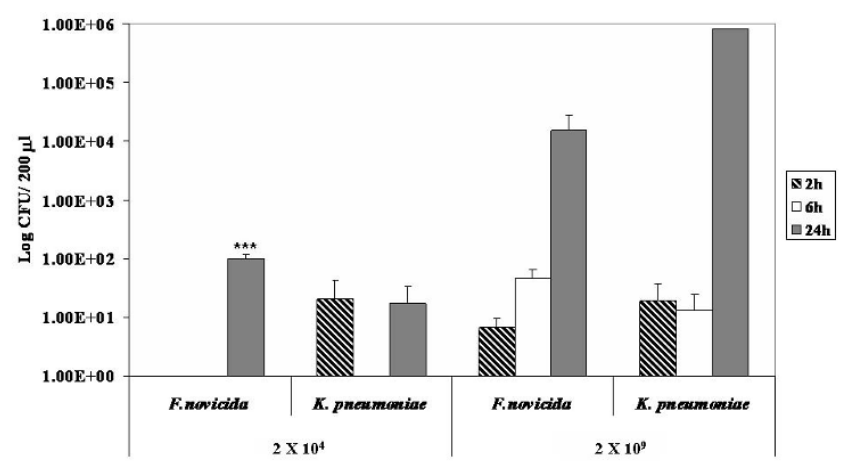

Figure 7

F. tularensis subsp. novicida and $K$. pneumoniae are found in blood of infected mice at early time points. In order to determine the presence of $F$. tularensis subsp. novicida as well as $K$. pneumoniae in blood at early time points mice were infected with $2 \times 10^{4} \mathrm{CFU} / 20 \mu \mathrm{l}$ and $2 \times 10^{9} \mathrm{CFU} /$ $20 \mu \mathrm{l}$. Data correspond to the average of 4 mice per infectious agent and dose and are given as Log CFU/200 $\mu$ l. Mice were sacrificed $2 \mathrm{hrs}, 6 \mathrm{hrs}$ and $24 \mathrm{hrs}$ pi, blood was plated and CFU were counted. The data obtained from mice infected with $F$. tularensis subsp. novicida at each time point and each bacterial dose was compared statistically by using a two tail Student's t-test to the data obtained from mice infected with $K$. pneumoniae. $*=p<0.05, * *=p<0.01$ and $* * *=p<0.005$.

Also of relevance, F. tularensis is known to cause illness in humans by ingestion, through cuts in the skin, as well as systemically but with usually different clinical outcomes. Therefore, mice were also inoculated with the same dose of bacteria by the i.g, i.d, i.p and i.v routes. Following i.g administration, the majority of labeled organisms appeared in the GI tract and remained so for 20 hrs p.i (Fig. 1 and Additional File 4 right). Substantial tropism to the lung was not evident by 20 hrs. Mice inoculated by the i.d route exhibited a different pattern (Fig. 1 and Additional File 5 right and left). The vast majority of the bacteria injected appeared to remain at the site of inoculation for the initial hours of infection. Consistent with this, the distribution of label in isolated tissues indicated that the vast majority of the label was localized to the skin and muscle at 20 hrs (Fig. 2). Nonetheless, the isotope distribution still suggested that there were bacteria in the blood and several other tissues by 20 hrs although there was no preferential tropism to the lung at this early time point. In the case of mice infected by the i.p route, most of the labeled bacterium 20 hrs after infection appeared to be present in the liver as seen by microPET images with redyellow color indicating the high concentration of bacteria in this tissue (Fig. 1), followed by the spleen and GI tract. In addition, our observations indicated that there was not a considerable amount of labeled bacteria present in the 
lung at this early time point (Fig. 1). Biodistribution data obtained for ${ }^{64} \mathrm{Cu}$ labeled $F$. tularensis subsp. novicida at this time point correlates with the microPET data, showing a substantial tropism for the liver followed by the spleen that had a significantly higher $\% \mathrm{ID} / \mathrm{g}$, than in the case of the i.n. infection ( $p<0.05$ ) (Fig. 2). In addition, statistical analysis showed that 20 hrs p.i, the lung, stomach and cecum showed a significantly higher $\% \mathrm{ID} / \mathrm{g}$ following i.n infection but not i.p infection $(\mathrm{p}<0.005$, p $<$ 0.05 and $\mathrm{p}<0.05$ respectively). When the i.v infection was performed, we observed that $20 \mathrm{hrs}$ p.i the majority of the labeled organisms were present in the liver, spleen and GI tract, seen by microPET image (Fig. 1). According to the biodistribution data obtained 20 hrs p.i, the majority of labeled $F$. tularensis subsp. novicida was present in the spleen and liver (Fig. 2), correlating with the microPET images (Fig. 1). Furthermore, statistical analyses showed that when comparing this infection route to the i.n route, there is a significantly higher tropism of $F$. tularensis subsp. novicida for spleen, liver and kidney ( $<<0.05$, $\mathrm{p}<$ 0.01 and $\mathrm{p}<0.005$ respectively) while there is a significantly lower tropism for the nasal cavity, trachea, lung, stomach and cecum ( $<<0.05, \mathrm{p}<0.005, \mathrm{p}<0.005, \mathrm{p}<$ 0.005 and $\mathrm{p}<0.05$ respectively) (Fig. 2 ).

\section{Effect of bacterial strain}

To test the potential effects of bacterial strains on dissemination, two different bacterial strains, E. coli and K. pneumoniae, were labeled with ${ }^{64} \mathrm{Cu}$-PTSM and administered i.n at the same dose of $2 \times 10^{9} \mathrm{CFU} / 20 \mu \mathrm{l}$ used for $F$. tularensis subsp. novicida. By both microPET analysis (Fig. 1) and ex vivo isotope distribution at $20 \mathrm{~h}$ (Fig. 5), E. coli exhibited the highest percentage of radioisotope in the digestive tract and a barely detectable percentage in the lung that was significantly lower than in the case of $F$. tularensis subsp. novicida infected mice ( $\mathrm{p}<0.005)$ (Fig. 5). In the case of K. pneumoniae infection (Fig. 1), another pulmonary pathogen, a larger percentage of labeled bacteria remained in the nasal cavity and less in the lung compared with $F$. tularensis subsp. novicida at all time points tested. Furthermore, our biodistribution data showed that by $20 \mathrm{hrs}$ p.i the \%ID/g obtained in the lung for K. pneumoniae infected mice are significantly lower than for $F$. tularensis subsp. novicida infected mice $(\mathrm{p}<0.005)$. In addition, spread of bacteria to the digestive tract appeared to be somewhat delayed compared with $F$. tularensis subsp. novicida. Interestingly, F. tularensis subsp. novicida shows a significantly higher tropism for cecum when compared to K. pneumoniae ( $\mathrm{p}<0.05$ ) but not with E. coli (Fig. 5). We also labeled LVS with ${ }^{64} \mathrm{Cu}$, infected mice by the i.n route and imaged them by MicroPET (data not shown). The results were similar to those obtained with i.n inoculation of $F$. tularensis subsp. novicida showing higher levels in the lung and GI tract. The biodistribution data is shown in Fig. 5.

\section{Isolation of Francisella tularensis subsp. novicida from gastrointestinal tract}

Our microPET results show a persistent localization of $F$. tularensis subsp. novicida in the GI tract. To test the presence of viable organisms in these tissues, we infected mice i.n with a $F$. tularensis subsp. novicida $\mathrm{Rif}^{+}$strain and determined the CFU in multiple tissues at 2 hrs, 6 hrs and 20 hrs p.i. We isolated F. tularensis subsp. novicida from lung, stomach, large intestine, small intestine and cecum as early as 2 hrs p.i (Fig. 6). The results obtained showed that the number of organisms isolated from lung, stomach, large intestine, small intestine and cecum increased $6 \mathrm{hrs}$ after infection although it was significant only for cecum ( $p<0.05)$. At 20 hrs after infection, the number of CFU isolated from the stomach, large intestine and small intestine showed a decrease, which was not statistically significant. However, the number of bacteria isolated from the lung at 20 hrs was significantly increased $(\mathrm{p}<0.005)$, while for the cecum the CFU remained about the same (Fig. 6).

\section{Presence of Francisella in blood at a lower dose}

As viable organisms were found in the blood by 24 hrs, it was surmised that Francisella is capable of creating an unusually rapid bacteremia. However, the microPET studies required a high dose of labeled organisms for image detection. Therefore, it was important to determine if mice receiving a lower dose would also exhibit viable organisms in the blood. For this analysis, an i.n dose of 2 $\times 10^{4} \mathrm{CFU} / 20 \mu \mathrm{l}$ was given which is comparable to the dose used in other published studies with Francisella [30]. The number of CFU/200 $\mu$ present in the blood of mice infected with $2 \times 10^{4} \mathrm{CFU} / 20 \mu \mathrm{l}$ of F. tularensis subsp. novicida was compared with that of mice receiving the higher dose used in the imaging studies $\left(2 \times 10^{9} \mathrm{CFU} / 20 \mu \mathrm{l}\right)$. Bacteria were found in blood of mice infected with the higher bacterial dose as early as 2 hrs p.i and increased sequentially at $6 \mathrm{hrs}$ and $24 \mathrm{hrs}$ (Fig. 7). In mice receiving the lower dose, bacteria were detected as early as 24 hrs p.i consistent with rapid entry into the bloodstream (Fig. 7). The same experiments were performed with high and low doses of K. pneumoniae. The results indicated that K. pneumoniae is also detectable in the blood at 24 hrs p.i at significantly lower levels than $F$. tularensis subsp. novicida when using the low infection dose $(\mathrm{p}<0.005)$. On the other hand, when comparing the presence of bacteria in blood using a higher infection dose at 24 hrs p.i, K. pneumoniae was present at higher levels but this difference was not statistically significant (Fig. 7).

\section{Discussion}

Several studies have been published to examine small animal infection models using in vivo bioluminescence imaging (BLI) to track the course of infection or determine the efficacy of anti-microbial therapies [31-49]. As 
reviewed previously [35], there are many advantages to in vivo imaging which include the ability to perform longitudinal studies with the same animal, identifying novel sites of infection such as the cecum [48] and gall bladder [42], and increased information per animal allowing for the use of fewer animals. One of the disadvantages of BLI is the inability to accurately localize the focal point of bioluminescence within the living animal as bioluminescence produces only two dimensional data, and the spatial resolution is limited [35]. In addition, the light is significantly attenuated per $\mathrm{cm}$ of tissue and scattered by fur and overlying tissues further complicating the data generated [35]. The use of microPET overcomes these disadvantages providing high resolution data that are three dimensional [16]. Thus, the entire depth of the body can be measured and specific organs visualized, particularly when combined with software that enables rotation of the image, and X-ray computed tomography (CT) that reveals the skeletal structure. Unfortunately, the CT capability only became available at the very end of our experiments. In addition, the high resolution of the microPET allows for accurate determination of radioactivity within user defined areas of interest. Using these measurements, both the CFU and the \% of input bacteria can be calculated without sacrificing the animal and performing labor intensive bacterial burden assays in order to track infection processes or assess therapeutic modalities. Moreover, microPET is more easily transitioned to the clinic as compared with BLI. The studies described herein used microPET technology in addition to traditional labeling techniques to assess the progressive spread of $F$. tularensis subsp. novicida during the initial hours of infection to explore mechanisms associated with its extreme virulence in mice.

When multiple mice were infected with radiolabeled $F$. tularensis subsp. novicida by inhalation followed by imaging, there was rapid widespread dissemination of organisms from the upper respiratory tract to the lung despite low inoculum volumes known to avoid direct introduction into the lung [50]. By $15 \mathrm{~min}$, labeled organisms were found in the lung and stomach with further spread through the GI tract by 20 hrs. Similar results were obtained with mice infected by the i.t route using two different protocols indicating that swallowing was unlikely to be involved in the rapid dissemination to the GI tract. By 20 hrs after pulmonary infection, radioactivity substantially decreased in the upper respiratory tract. Activity in the lung was maintained and in several animals, accumulated to a greater degree suggesting an early tropism. This was confirmed by the distribution of radioisotope post necropsy where the highest levels of label were consistently found in the lung at $20 \mathrm{hrs}$. Comparable results were obtained when F. tularensis LVS was inoculated i.n. at the same dose suggesting similar dissemination patterns in
Francisella. Similarly, bacterial burden assays have previously shown that mice intranasally infected with a low bacterial dose of Francisella show a relatively high bacterial burden in lung as early as 1 day post-infection $[51,52]$. Therefore, regardless of the inoculum dose, Francisella has a high tropism for the lung when infected through the aerosol route.

Bacterial burden assays correlated with the imaging and biodistribution data. A Rif ${ }^{+}$strain with equivalent virulence allowed assessment of viable bacteria in the GI tract. The results obtained show that there is a wide dissemination of bacteria as early as 2 hrs after i.n. infection, and CFU could be isolated from multiple organs including lung, stomach, small intestine, cecum and large intestine. It has been shown previously that Francisella can cause a typhoid-like disease [9] and survive the harsh environment of the GI tract in mice [53]. However, the rapidity of spread to the gut after i.n infection was unexpected. One possible explanation of the rapid dissemination to the GI tract in our model could involve a hematogenous and/or lymphatogenous way through the Nasal Associated Lymphoid Tissue (NALT). It has been previously reported [54] that the NALT is composed of mainly B cells, to a lesser extent $\mathrm{T}$ cells and a small proportion of macrophages (CD11b+cells), and that the percentages of these cell types observed in NALT are similar to the percentages observed in spleen [54]. Since it is known that Francisella survives and replicates inside macrophages, a possible way of dissemination from the nasal passages could be by macrophages present in the NALT acting as 'Trojan horses', assuring the protection from the immune system and facilitating a rapid dissemination to other tissues. This has been observed for Salmonella typhimurium by trafficking through T, B cells and macrophages [55,56].

One interesting aspect of working with microPET technology is the possibility to identify novel sites of infection. In our case, these experiments allowed us to identify the concentration of $F$. tularensis subsp. novicida in the cecum, which has not been described previously. Several studies using different organisms known to invade the gut including Citrobacter rodentium, Helicobacter pylori and Burkholderia cepacia appear to colonize the cecum $[38,48,57]$. In addition, it has been previously reported that intranasally delivered $S$. typhimurium in swine is present in cecum as early as 3 hrs p.i [58]. The cecum, particularly the cecal patch, contain lymphoid tissue that could play an important role in immunity and possibly further bacterial dissemination. This aspect is currently under study in our laboratory.

K. pneumoniae, another pulmonary pathogen, was used for comparison as was a gut associated E. coli clinical isolate, and both were administered i.n. Interestingly, $K$. 
pneumoniae in contrast to $F$. tularensis subsp. novicida exhibited little or no dissemination to the stomach during the first two hours and was mainly confined to the nasal cavity and trachea. Even at 20 hrs, the largest \% of label was still present in the nasal cavity although trafficking to the GI tract was apparent by then. Interestingly, at these early time points, the lung was not the major focus of infection. In the case of E. coli, organisms at 20 hrs were mainly confined to the GI tract. The results indicate distinct distribution patterns of pathogenic bacteria during the first hours of infection when mice are given the same number of organisms and by the identical route. Moreover, the early tropism to the lung in the case of Francisella was dependent upon viable organisms as non-viable, biosynthetically ${ }^{35} \mathrm{~S}$ labeled bacteria failed to preferentially traffic to the lung at $20 \mathrm{hrs}$ compared to the viable (unfixed) labeled bacteria. More of the non-viable organisms appeared to traffic to the gall bladder as compared to the viable labeled bacteria in this tissue at the same time point. This suggests that the viable organisms begin colonizing the lung rapidly.

Initially, we thought that the extreme rapidity of dissemination was associated with the ability of Francisella to enter the bloodstream quickly as CFU could be detected in the blood at 20 hrs p.i. However, one of the disadvantages of in vivo imaging in general is the requirement to use large doses of organisms in order to visualize the images. Therefore, we questioned if more physiological doses of $10^{3}$ or $10^{4}$ organisms would result in a detectable bacteremia. And in fact, even at the lower doses, clear evidence of viable bacteria were found by 20 hrs supporting this contention, and likely explaining the presence of radioactivity in essentially all tissues analyzed by both labeling techniques. However, we then tested K. pneumoniae for its ability to establish a bacteremia at these early time points. Significantly, K. pneumoniae at both high and low doses entered the blood stream, and if anything, at increased levels with detection in some mice at earlier time points. Despite this, $K$. pneumoniae infected mice did not appear overtly ill whereas F. tularensis subsp. novicida mice did as judged by pilo-erection, lethargy, and hunched posture. Interestingly, K. pneumoniae maintained the bulk of the inoculum in the nasal cavity in contrast to F. tularensis subsp. novicida, and it is possible that this is an important site for entrance to the blood. In fact, bacteremia has been reported in tularemia $[10,59]$ and the presence of F. tularensis LVS as well as SchuS4 strains in blood early after i.d infection has been described [60]. Nonetheless, the extreme virulence of $F$. tularensis subsp. novicida in mice may not be attributed solely to blood vasculature ingress.

Francisella tularensis is a bacterium that can adapt to many different environments including soil, ground water, and growth in amoeba [11]. It also replicates intracellularly within humans and a variety of other species causing significant morbidity and mortality. It contains a number of genes that facilitate survival under a variety of conditions [61]. Correlative to this, Francisella is known to cause infection in humans by inhalation, ingestion, eye contact, insect bites, and cuts in the skin [3,9]. Interestingly, the pulmonary route causes the most severe infections with substantial mortality, although other routes of infection have been known to develop into severe infections but with less frequency [9]. Therefore, other routes of infection were tested using the same number of bacteria. With oral infection (i.g), the majority of radiolabeled Francisella trafficked and remained in the GI tract through 20 hrs p.i. After an i.d injection during this same time period, most of the organisms remained in the skin and muscle tissue. Both oral and i.d (cuts in skin) routes cause illness, but usually less severe in patients, and it is possible that this alteration in trafficking is involved in the decreased severity. Mice were also infected by the i.p and i.v routes. In both cases, the majority of the bacteria were localized to the liver and spleen and to a lesser extent to the GI tract and the lung. Comparing the biodistribution data obtained at 20 hrs p.i among all of the infection routes, the results suggest that the numbers of $F$. tularensis subsp. novicida bacteria present in mice after i.n and i.t infection are higher in the lung than in mice infected through any of the other infection routes tested despite the same infection doses. Several studies have used LVS to examine various routes of inoculation, mostly at later time points of infection to study colonization $[53,62,63]$. However, KuoLee et al. [53], reported CFU in lung and GI tract at 1 day p.i following a dose of $10^{8} \mathrm{CFU}$ of LVS, consistent with our findings. In addition, Woolard et al. [63] used an i.d dose of $10^{5} \mathrm{CFU}$ of LVS and showed barely detectable CFU in the lung and spleen at 1 day consistent with our radiodistribution data at $20 \mathrm{hrs}$ p.i. We speculate that the different trafficking patterns are due, in fact by differences in the innate immune response mounted depending on the initial tissue impacted as suggested by recent studies of organ specific immunity [64-69]. We and others have found evidence of a delay in the innate immune response following i.n infection, indicated by the absence of proinflammatory cytokines and chemokines early after infection ( 6 hrs p.i - 48 hrs p.i) and beginning to increase only after 72 hrs p.i $[70,71]$. We propose that the acute virulence associated with inhaled Francisella is its extremely rapid colonization of the lung leading to pulmonary failure and eventual multiple organ failure before an effective immune response can be elicited. To test this, future studies will use microPET with CT capabilities together with radiolabeled antibodies to both bacteria and distinct immune cell subsets so that continued dissemination, increases in bacterial biomass, and the disease process can be evaluated at later time points. 


\section{Conclusion}

By using various labeling techniques, imaging, and bacterial counting, we conclude that Francisella rapidly disseminates within hours to multiple tissues regardless of the route of infection with the possible exception of the intradermal route. However, the route of infection alters the trafficking patterns. In the case of the pulmonary route, which is the most dangerous, the bacteria rapidly traffic to the lung and throughout the GI tract but by 20 hrs appears to preferentially colonize the lung indicating an early tropism to this organ. We speculate that the mode of transmission alters the severity of the disease because of documented differences in organ specific immunity.

\section{Methods}

Bacterial strains and culture media

Francisella tularensis subsp. novicida strain U112 was obtained from Dr. Bernard Arulanandam (UTSA) through Dr. Fran Nano (University of Victoria). It was grown in Tripticase Soy Agar/Broth (Becton Dickinson), supplemented with $0.1 \%$ cysteine (TSAcys). Escherichia coli (clinical isolate) was obtained from Dr. Stephen Mattingly (UTHSCSA) and was grown in Luria Bertani Agar (LB medium). Klebsiella pneumoniae (ATCC \# 43816) was obtained from Dr. Peter Dube (UTHSCSA) and was grown in LB. Bacteria were resuspended in broth and then taken to a titer of $2 \times 10^{9}$ colony forming units (CFU)/300 $\mu$ l.

\section{Radiolabeling of bacteria with [ ${ }^{64} \mathrm{Cu}$ ] PTSM}

Resuspended bacteria were added to $400 \mu \mathrm{Ci}$ [ ${ }^{64} \mathrm{Cu}$ ] PTSM and incubated in a water bath at $42^{\circ} \mathrm{C}$ for $1 \mathrm{hr}$. $\left[{ }^{64} \mathrm{Cu}\right]$ was conjugated to PTSM as previously described [72]. Radiolabeled bacteria were centrifuged at $15000 \mathrm{~g}$ for $4 \mathrm{~min}$. Supernatants were removed, and both pellets and supernatants were measured for radioactivity to determine radiolabeling efficiency of the bacteria. Preliminary radiolabeling studies were performed using different bacterial doses ranging from $10^{3}$ to $10^{9} \mathrm{CFU} / 300 \mu \mathrm{l}$. It was determined that the concentration of $10^{9} / 300 \mu \mathrm{l}$ was most efficiently labeled and that doses of $10^{9}$ labeled organisms were required for visualization by microPET. In addition, control experiments were performed to determine the effect of labeling on viability of the bacteria with time. It was found that there was no change in the viability of the organisms after 90 min of labeling indicating a lack of toxicity associated with the labeling method. In addition, the potential leakage of label was determined by incubating labeled and washed organisms for extended periods. After incubation, bacteria were washed again, and the amount of label in the supernatant and pellets determined at 24 hrs. $79.5+/-2.1 \%$ of the label remained in the pellet indicating the stability of the labeling process. In addition, bacteria viability post-labeling was checked at $90 \mathrm{~min}, 24$ hrs and 48 hrs post-infection and was found to be
$114.5 \%, 43.8 \%$ and $57.4 \%$ respectively. Labeled organisms were resuspended in sterile $1 \times$ phosphate-buffered saline (PBS) for inoculation of mice.

\section{In vivo bacterial biodistribution}

Labeled bacteria pellets were resuspended in $30 \mu \mathrm{l}$ or 50 $\mu \mathrm{l}$ of sterile $1 \times \mathrm{PBS}$ to a final concentration of $2 \times 10^{9} \mathrm{CFU} /$ $20-25 \mu$ intranasally (i.n) or $2 \times 10^{9} \mathrm{CFU} / 50 \mu \mathrm{l}$ intradermal (i.d). C57BL/ 6 females $6-8$ wk old were anesthetized with vaporized isofluorane for the initial experiments and later by intramuscular injection of $100 \mu \mathrm{l}$ of ketaminexylazine mixture containing $(30 \mathrm{mg} / \mathrm{mL}$ ketamine, $4 \mathrm{mg} /$ $\mathrm{mL}$ xylazine in $1 \times \mathrm{PBS}$ ). No apparent differences in images were observed between the two methods of anesthesia. Mice were then i.n inoculated with 10-12.5 $\mu$ l of bacterial suspension in each nostril drop by drop thus allowing the mice to slowly inhale the inoculum. Intradermal inoculations were done by injecting $50 \mu \mathrm{l}$ of $2 \times 10^{9} \mathrm{CFU}$ in the right leg of mice. A total of fifteen mice were inoculated i.n, nine with $F$. tularensis subsp. novicida, three more with E. coli and three with $K$. penumoniae. Additional routes of inoculation included intratracheal (i.t), intragastric (i.g), intraperitoneal (i.p) and intravenous (i.v) inoculations of ${ }^{64} \mathrm{Cu}$ labeled $F$. tularensis subsp. novicida using $2 \times 10^{9}$ $\mathrm{CFU} / 50 \mu \mathrm{l}$ for the i.t and i.v infections and $2 \times 10^{9} \mathrm{CFU} /$ $100 \mu \mathrm{l}$ for the i.g and i.p infections; three mice were inoculated with $F$. tularensis subsp. novicida for each of the routes. The i.t infection was performed according to the procedure of Rubins et al. (40). Briefly, mice were anesthetized with vaporized isofluorane, suspended in an upright position, and the tongue was extended outwards and towards the side of the mouth with forceps. The inoculum was then delivered by pipette to the back of the throat while covering the nose. This procedure has been shown to prevent swallowing with the vast majority of the inoculum delivered to the trachea and lungs $[28,29]$. The i.g infection was performed by using a gavage needle to directly deliver the inoculum into the stomach, while the intraperitoneal infection was accomplished by injecting $100 \mu \mathrm{l}$ of the inoculum with a 23-gauge needle directly in the right bottom quadrant of the peritoneum. Finally, the intravenous infection was achieved by injecting $50 \mu \mathrm{l}$ of the inoculum in the mice tail vein with a 28 -gauge needle. All animals were imaged for 15-20 min, immediately after infection (labeled $0.25 \mathrm{hr}$ ) and at 2 and $20 \mathrm{hrs}$ by using a microPET-R4 rodent scanner (Concorde Microsystems, Knoxville, TN, USA). MicroPET provides a $10 \mathrm{~cm}$ by $8 \mathrm{~cm}$ field of view with a reconstructed resolution of 2.25 $\mathrm{mm}$ in the central $40 \mathrm{~mm}$ of the field of view. Images are reconstructed using Fourier re-binning followed by twodimensional filtered backprojection. Towards the end of our studies, a FLEX Pre-Clinical Platform (Gamma-Medica-Ideas, Northridge, CA) was acquired; this allowed the acquisition of an X-ray computed tomography (CT) image 
permitting the visualization of the skeletal structure of the mice being analyzed. The FLEX pre-Clinical Platform CT device provides an $8.7 \mathrm{~cm}$ field of view, fly acquisition, 2 $\times 2$ binning, and 256 projections, with a spatial resolution of $\sim 100 \mu \mathrm{m}$. This procedure was performed for $1 \mathrm{~min}$ prior to acquire the microPET image. We made use of this device to image mice that had been previously infected with ${ }^{64} \mathrm{Cu}$ labeled $F$. tularensis subsp. novicida by the i.n, i.p and i.v routes of infection.

Once the mice had been scanned for the last time point, they were sacrificed and various tissues (as shown in Fig 2) were harvested in order to quantify the amount of ${ }^{64} \mathrm{Cu}$ still present in them by using an automatic well-type gamma counter ( $\gamma 8000$ Beckman Coulter Fullerton, CA). Finally, some of the tissues harvested from $F$. tularensis subsp. novicida infected animals were weighed, homogenized in $1 \times$ PBS, serially diluted, and plated on TSAcys (Becton Dickinson) to determine CFU/g of tissue in the i.n infected mice. All the experimental procedures were in compliance with federal guidelines and the institutional animal care and use committee.

\section{Isolation of rifampicin resistant Francisella tularensis subsp. novicida from the gastrointestinal (GI) tract}

In order to test for CFU in the GI tract, several rifampicin resistant $F$. tularensis subsp. novicida (F. tularensis subsp. novicida $\mathrm{Rif}^{+}$) isolates were generated and tested for virulence. F. tularensis subsp. novicida was grown in a liquid culture in tripticase soy broth (TSB) supplemented with $0.1 \% \mathrm{~L}$-cysteine with agitation at $37^{\circ} \mathrm{C}$ overnight (ON). $1 \mathrm{~mL}$ of culture was then centrifuged at 13,000 rpm for 4 min; the cell pellet was resuspended in $100 \mu \mathrm{l}$ of $1 \times$ sterile PBS and plated on TSAcys plates containing $200 \mu \mathrm{g} /$ $\mathrm{mL}$ rifampicin. Rif ${ }^{+}$bacteria were streaked again on TSAcys plates containing $200 \mu \mathrm{g} / \mathrm{mL}$ rifampicin. Colonies that grew better were then streaked again on TSAcys plates containing $30 \mu \mathrm{g} / \mathrm{mL}$ rifampicin. A Rif ${ }^{+}$isolate that was shown to have equivalent virulence to the wt strain $\left(\mathrm{LD}_{50} 10\right)$ was then used in subsequent studies. For analyses of the GI tract, nine C57BL/ 6 females $6-8$ wk old were anesthetized and i.n inoculated with $2 \times 10^{9} \mathrm{CFU} /$ $20 \mu \mathrm{l}$ of $F$. tularensis subsp. novicida Rif $^{+}$bacterial suspension. At serial time points, mice were sacrificed after anesthesia using a mixture of ketamine-xylazine. Lung, stomach, large intestine, small intestine and cecum were collected and organs homogenized; serial dilutions were made and plated on TSAcys plates containing $30 \mu \mathrm{g} / \mathrm{mL}$ rifampicin.

\section{Metabolic labeling of bacteria with ${ }^{35} \mathrm{~S}$}

F. tularensis subsp. novicida cultures $(50 \mathrm{~mL})$ were incubated at $37^{\circ} \mathrm{C}$ for $2 \mathrm{hrs}$ with agitation. Bacterial cultures were then centrifuged, supernatants were removed and cell pellets were washed twice with either TSB or LB liquid medium. Bacteria were re-suspended in $50 \mathrm{~mL}$ DMEM medium without L-glutamine, L-methionine and Lcysteine (MP Biomedicals) and incubated at $37^{\circ} \mathrm{C}$ for 15 min with agitation. Subsequently, $230 \mu \mathrm{Ci}$ of $35 \mathrm{~S}$ were added to each bacterial culture and incubated for an additional 2 hrs. Bacterial cultures were then concentrated and the amount of ${ }^{35} \mathrm{~S}$ present in the cell pellets and supernatants were measured to determine efficiency of labeling. Once the bacteria were labeled, serial dilutions were prepared and plated on TSAcys to determine CFU.

\section{Biodistribution of labeled bacteria with ${ }^{35} \mathrm{~S}$}

Labeled bacterial pellets were resuspended in $1 \times$ PBS to a final concentration of $2 \times 10^{9}$ CFU. Mice (C57BL/6 6-8 wk old) were anesthetized and inoculated i.n with 20-25 $\mu \mathrm{l}$ of the bacterial suspension and inoculated i.t with $50 \mu \mathrm{l}$ of inoculum. In order to infect mice by the i.t route an endotracheal intubation was performed by using a BioLite small animal intubation system (BioTex, Inc., TX). Briefly, mice were anesthetized by intramuscular injection of ketamine-xylazine as previously described. Subsequently mice were suspended from the incisor wire on the intubation stand, followed by the tracheal intubation with a flexible intravenous catheter over a fiber-optic laser attached to an illuminator that allows a better visualization of the oralpharyngeal cavity. Once inside the trachea, the fiberoptic was drawn out and a $1 \mathrm{~mL}$ syringe was plugged to the catheter, and the inculum was delivered to the mouse. This method of inoculation allowed us to avoid any accidental swallowing of the inoculum.

After infection, mice were sacrificed at 20 hrs p.i in the case of i.n infected mice and at 1-2 hrs and 20 hrs postinoculation in the case of i.t infected mice, various tissues were removed, and the amount of ${ }^{35} \mathrm{~S}$ in each tissue was determined by using a multi-purpose scintillation counter (LS6500 Beckman Coulter Fullerton, CA). In addition, several tissues were weighed, homogenized in $1 \times \mathrm{PBS}$, serially diluted, and plated to determine CFU/g of tissue in the case of the i.n infected mice.

\section{Authors' contributions}

SSO carried out the imaging studies, including biodistribution, metabolic labeling of the bacterium, bacterial burden assays, data analysis and writing of the manuscript. ZJW carried out the imaging studies including bacterial radiolabeling and data analysis. CAM carried out the imaging studies, including biodistribution, metabolic labeling of the bacterium and bacterial burden assays. TC participated in the imaging data analysis. LQ participated in the imaging studies, including biodistribution, metabolic labeling of the bacterium and bacterial burden assays. EGM participated in the imaging studies, including 
biodistribution, metabolic labeling of the bacterium and bacterial burden assays. PAJ helped supervise the use of the MicroPET. JMT conceived the study, participated in its design and coordination, and has been involved in writing and critically reviewing the manuscript.

\section{Additional material}

\section{Additional file 1}

Movie representing in vivo localization of ${ }^{64} \mathrm{Cu}$ labeled $\mathrm{F}$. tularensis subsp. novicida following i.n infection. MicroPET and CT video of a mouse infected i.n with ${ }^{64} \mathrm{Cu}$ labeled $\mathrm{F}$. tularensis subsp. novicida 0.25 hrs p.i. The mouse shown in this movie corresponds to one different than the one depicted in Figure 1.

Click here for file

[http://www.biomedcentral.com/content/supplementary/14712180-8-215-S1.mpg]

\section{Additional file 2}

Movie representing in vivo localization of ${ }^{64} \mathrm{Cu}$ labeled $\mathrm{F}$. tularensis subsp. novicida following i.p infection. MicroPET and CT video of a mouse infected i.p with ${ }^{64} \mathrm{Cu}$ labeled $\mathrm{F}$. tularensis subsp. novicida 0.25 hrs p.i. The mouse shown in this movie corresponds to one different than the one depicted in Figure 1.

Click here for file

[http://www.biomedcentral.com/content/supplementary/1471-

2180-8-215-S2.mpg]

\section{Additional file 3}

Movie representing in vivo localization of ${ }^{64} \mathrm{Cu}$ labeled $\mathrm{F}$. tularensis subsp. novicida following i.v infection. MicroPET and CT video of a mouse infected i.v with ${ }^{64} \mathrm{Cu}$ labeled $\mathrm{F}$. tularensis subsp. novicida 0.25 hrs p.i. The mouse shown in this movie corresponds to one different than the one depicted in Figure 1.

Click here for file

[http://www.biomedcentral.com/content/supplementary/14712180-8-215-S3.mpg]

\section{Additional file 4}

Movie representing in vivo localization of ${ }^{64} \mathrm{Cu}$ labeled $\mathrm{F}$. tularensis subsp. novicida following i.t and i.g infections. MicroPET video of two mice, one infected i.t with ${ }^{64} \mathrm{Cu}$ labeled $\mathrm{F}$. tularensis subsp. novicida at $0.25 \mathrm{hrs}$ p.i (left when the image is still) and another one infected i.g with ${ }^{64} \mathrm{Cu}$ labeled F. tularensis subsp. novicida 0.25 hrs p.i (right when the image is still). The mice shown in this movie correspond to mice different than the ones depicted in Figure 1.

Click here for file

[http://www.biomedcentral.com/content/supplementary/14712180-8-215-S4.mpg]

\section{Additional file 5}

Movie representing in vivo localization of ${ }^{64} \mathrm{Cu}$ labeled $\mathrm{F}$. tularensis subsp. novicida following i.d infection. MicroPET video of two mice infected i.d with ${ }^{64} \mathrm{Cu}$ labeled $\mathrm{F}$. tularensis subsp. novicida $0.25 \mathrm{hrs}$ p.i (right and left). One of the mice shown in this movie corresponds to the one depicted in Figure 1 while the other mouse corresponds to another one imaged at the same time.

Click here for file

[http://www.biomedcentral.com/content/supplementary/14712180-8-215-S5.mpeg]

\section{Additional file 6}

Graph representing bacterial load following i.n infection with ${ }^{64} \mathrm{Cu}$ labeled $\mathrm{F}$. tularensis subsp. novicida. In order to determine the presence of viable ${ }^{64} \mathrm{Cu}$ labeled $\mathrm{F}$. tularensis subsp. novicida in different tissues after infection, bacterial burden assays were performed. Data represent the mean with range of two mice and are given as Log CFU/g of tissue. Lung, liver, bladder and blood were harvested at $20 \mathrm{hrs} \mathrm{p.i.}{ }^{64} \mathrm{Cu}$ labeled F. tularensis subsp. novicida was isolated from all the tissues analyzed at this time point.

Click here for file

[http://www.biomedcentral.com/content/supplementary/14712180-8-215-S6.tiff]

\section{Acknowledgements}

This work was supported by a NIH AI 59703, POI Al057986, NS 35974 and in part by San Antonio Life Science Institute ( 10003 I77) and a start-up fund from Department of Radiology, University of Texas Health Science Center at San Antonio. The ${ }^{64} \mathrm{Cu}$ was provided by Washington University Research Resource in Radionuclide Research (R24CA086307).

We thank David Lewis, Sergio Leal and Rick Perez for their assistance in the acquisition of images during the microPET studies. We are also grateful to Dr. Peter $\mathrm{H}$. Dube for his advice and providing the strain of $K$. pneumoniae used in our studies, Dr. Stephen Mattingly for providing the strain of $E$. coli, Dr. Carlos J. Orihuela for instructing us on how to perform the intratracheal infection and Dr. Marcel Perret-Gentil DVM for his help with the endotracheal entubation of mice. The authors thank Dr. William Phillips for his helpful discussions regarding this project. We also thank Dr. Jorge Alvarez for his collaboration during the preparation of the figures for this manuscript.

\section{References}

I. Abd H, Johansson T, Golovliov I, Sandstrom G, Forsman M: Survival and growth of Francisella tularensis in Acanthamoeba castellanii. Appl Environ Microbiol 2003, 69(I):600-606.

2. Lauriano CM, Barker JR, Yoon SS, Nano FE, Arulanandam BP, Hassett $\mathrm{DJ}$, Klose KE: MgIA regulates transcription of virulence factors necessary for Francisella tularensis intraamoebae and intramacrophage survival. Proc Natl Acad Sci USA 2004, I0I(12):4246-4249.

3. Oyston PC, Sjostedt A, Titball RW: Tularaemia: bioterrorism defence renews interest in Francisella tularensis. Nat Rev Microbiol 2004, 2(I 2):967-978.

4. Zeidner NS, Carter LG, Monteneiri JA, Petersen JM, Schriefer M, Gage KL, Hall G, Chu MC: An outbreak of Francisella tularensis in captive prairie dogs: an immunohistochemical analysis. J Vet Diagn Invest 2004, I6(2):150-152.

5. Sjostedt A: Intracellular survival mechanisms of Francisella tularensis, a stealth pathogen. Microbes Infect 2006, 8(2):56|-567.

6. Bosio CM, Dow SW: Francisella tularensis induces aberrant activation of pulmonary dendritic cells. J Immunol 2005, I75(10):6792-680I.

7. Hall JD, Craven RR, Fuller JR, Pickles RJ, Kawula TH: Francisella tularensis replicates within alveolar type II epithelial cells in vitro and in vivo following inhalation. Infect Immun 2007, 75(2): 1034-1039.

8. Chen W, KuoLee R, Shen H, Conlan JW: Susceptibility of immunodeficient mice to aerosol and systemic infection with virulent strains of Francisella tularensis. Microb Pathog 2004, 36(6):3II-3I8.

9. Dennis DT, Inglesby TV, Henderson DA, Bartlett JG, Ascher MS, Eitzen E, Fine AD, Friedlander AM, Hauer J, Layton M, Lilibridge SR, McDade JE, Osterholm MT, O'Toole T, Parker G, Perl TM, Russell 
PK, Tonat K: Tularemia as a biological weapon: medical and public health management. Jama 200I, 285(2I):2763-2773.

10. Ellis J, Oyston PC, Green M, Titball RW: Tularemia. Clin Microbiol Rev 2002, I 5(4):63।-646.

II. Elkins KL, Cowley SC, Collazo CM: Francisella: a little bug hits the big time. Expert Rev Vaccines 2003, 2(6):735-738.

12. Tarnvik A: Nature of protective immunity to Francisella tularensis. Rev Infect Dis 1989, I I (3):440-45 I.

13. Weber S, Bauer A: Small animal PET: aspects of performance assessment. Eur J Nucl Med Mol Imaging 2004, 3 I ( I I): I 545-I 555.

14. Phelps ME: Inaugural article: positron emission tomography provides molecular imaging of biological processes. Proc Natl Acad Sci USA 2000, 97( 16):9226-9233.

I5. Matsui K, Wang Z, McCarthy TJ, Allen PM, Reichert DE: Quantitation and visualization of tumor-specific $T$ cells in the secondary lymphoid organs during and after tumor elimination by PET. Nucl Med Biol 2004, 3 I(8): I02 I- I03 I.

16. Sossi V, Ruth TJ: Micropet imaging: in vivo biochemistry in small animals. J Neural Transm 2005, I I 2(3):3 I 9-330.

17. Myers R: The biological application of small animal PET imaging. Nucl Med Biol 200I, 28(5):585-593.

18. Del Guerra A, Belcari N: Advances in animal PET scanners. $Q J$ Nucl Med 2002, 46(I):35-47.

19. Blower PJ, Lewis JS, Zweit J: Copper radionuclides and radiopharmaceuticals in nuclear medicine. Nucl Med Biol 1996, 23(8):957-980.

20. Lewis MR, Raubitschek A, Shively JE: A facile, water-soluble method for modification of proteins with DOTA. Use of elevated temperature and optimized $\mathrm{pH}$ to achieve high specific activity and high chelate stability in radiolabeled immunoconjugates. Bioconjug Chem 1994, 5(6):565-576.

21. Wipke BT, Wang Z, Nagengast W, Reichert DE, Allen PM: Staging the initiation of autoantibody-induced arthritis: a critica role for immune complexes. I Immunol 2004 I 72(I 2):7694-7702.

22. Wipke BT, Wang Z, Kim J, McCarthy TJ, Allen PM: Dynamic visualization of a joint-specific autoimmune response through positron emission tomography. Nat Immunol 2002, 3(4):366-372.

23. Diaz LA Jr, Foss CA, Thornton K, Nimmagadda S, Endres CJ, Uzuner O, Seyler TM, Ulrich SD, Conway J, Bettegowda C, Agrawal N, Cheong I, Zhang X, Ladenson PW, Vogelstein BN, Mont MA, Zhou S, Kinzler KW, Vogelstein B, Pomper MG: Imaging of musculoskeletal bacterial infections by [124I]FIAU-PET/CT. PLOS ONE 2007, 2(1 0):el007.

24. Bettegowda C, Foss CA, Cheong I, Wang Y, Diaz L, Agrawal N, Fox J, Dick J, Dang LH, Zhou S, Kinzler KW, Vogelstein B, Pomper MG Imaging bacterial infections with radiolabeled I-(2'-deoxy-2'fluoro-beta-D-arabinofuranosyl)-5-iodouracil. Proc Natl Acad Sci USA 2005, I 02(4): I |45- I I 50.

25. Brader P, Stritzker J, Ried CC, Zanzonico P, Cai S, Burnazi EM, Ghani ER, Hricak H, Szalay AA, Fong Y, Blasberg R: Escherichia coli Nissle 1917 facilitates tumor detection by positron emission tomography and optical imaging. Clin Cancer Res 2008, I 4(8):2295-2302.

26. Eyles JE, Spiers ID, Williamson ED, Alpar HO: Tissue distribution of radioactivity following intranasal administration of radioactive microspheres. J Pharm Pharmacol 2001, 53(5):601-607.

27. Pickett TE, Pasetti MF, Galen JE, Sztein MB, Levine MM: In vivo characterization of the murine intranasal model for assessing the immunogenicity of attenuated Salmonella enterica serovar Typhi strains as live mucosal vaccines and as live vectors. Infect Immun 2000, 68(I):205-2I3.

28. Orihuela CJ, Gao G, Francis KP, Yu J, Tuomanen El: Tissue-specific contributions of pneumococcal virulence factors to pathogenesis. J Infect Dis 2004, I 90(9): 166I-1669.

29. Rubins JB, Charboneau D, Fasching C, Berry AM, Paton JC, Alexander JE, Andrew PW, Mitchell TJ, Janoff EN: Distinct roles for pneumolysin's cytotoxic and complement activities in the pathogenesis of pneumococcal pneumonia. Am J Respir Crit Care Med 1996, I 53(4 Pt I): I339-1346.

30. Duckett NS, Olmos S, Durrant DM, Metzger DW: Intranasal interleukin- 12 treatment for protection against respiratory infection with the Francisella tularensis live vaccine strain. Infect Immun 2005, 73(4):2306-23II.
31. BitMansour A, Burns SM, Traver D, Akashi K, Contag CH, Weissman IL, Brown JM: Myeloid progenitors protect against invasive aspergillosis and Pseudomonas aeruginosa infection following hematopoietic stem cell transplantation. Blood 2002, I 00( I3):4660-4667.

32. Burns SM, Joh D, Francis KP, Shortliffe LD, Gruber CA, Contag PR, Contag $\mathrm{CH}$ : Revealing the spatiotemporal patterns of bacterial infectious diseases using bioluminescent pathogens and whole body imaging. Contrib Microbiol 200I, 9:7I-88.

33. Contag $\mathrm{CH}$, Contag PR, Mullins Jl, Spilman SD, Stevenson DK, Benaron DA: Photonic detection of bacterial pathogens in living hosts. Mol Microbiol I995, I 8(4):593-603.

34. Cook SH, Griffin DE: Luciferase imaging of a neurotropic viral infection in intact animals. J Virol 2003, 77(9):5333-5338.

35. Doyle TC, Burns SM, Contag $\mathrm{CH}$ : In vivo bioluminescence imaging for integrated studies of infection. Cell Microbiol 2004, 6(4):303-317.

36. Francis KP, Joh D, Bellinger-Kawahara C, Hawkinson MJ, Purchio TF, Contag PR: Monitoring bioluminescent Staphylococcus aureus infections in living mice using a novel luxABCDE construct. Infect Immun 2000, 68(6):3594-3600.

37. Francis KP, Yu J, Bellinger-Kawahara C, Joh D, Hawkinson MJ, Xiao G, Purchio TF, Caparon MG, Lipsitch M, Contag PR: Visualizing pneumococcal infections in the lungs of live mice using bioluminescent Streptococcus pneumoniae transformed with a novel gram-positive lux transposon. Infect Immun 200I, 69(5):3350-3358.

38. George SE, Nelson GM, Kohan MJ, Brooks LR, Boyd C: Colonization and clearance of environmental microbial agents upon intranasal exposure of strain $\mathrm{C} 3 \mathrm{H} / \mathrm{HeJ}$ mice. J Toxicol Environ Health A 1999, 56(6):4|9-43|.

39. Greer LF 3rd, Szalay AA: Imaging of light emission from the expression of luciferases in living cells and organisms: a review. Luminescence 2002, I 7(I):43-74

40. Hamblin MR, O'Donnell DA, Murthy N, Contag CH, Hasan T: Rapid control of wound infections by targeted photodynamic therapy monitored by in vivo bioluminescence imaging. Photochem Photobiol 2002, 75(I):5 I-57.

4I. Hamblin MR, Zahra T, Contag CH, McManus AT, Hasan T: Optical monitoring and treatment of potentially lethal wound infections in vivo. J Infect Dis 2003, I 87( I I): I717-1725.

42. Hardy J, Francis KP, DeBoer M, Chu P, Gibbs K, Contag CH: Extracellular replication of Listeria monocytogenes in the murine gall bladder. Science 2004, 303(5659):85I-853.

43. Kadurugamuwa JL, Sin LV, Yu J, Francis KP, Kimura R, Purchio T, Contag PR: Rapid direct method for monitoring antibiotics in a mouse model of bacterial biofilm infection. Antimicrob Agents Chemother 2003, 47( I 0):3 | 30-3 I 37.

44. Luker GD, Bardill JP, Prior JL, Pica CM, Piwnica-Worms D, Leib DA: Noninvasive bioluminescence imaging of herpes simplex virus type I infection and therapy in living mice. J Virol 2002, 76(23): $12149-12161$

45. McCullers JA, Bartmess KC: Role of neuraminidase in lethal synergism between influenza virus and Streptococcus pneumoniae. J Infect Dis 2003, I 87(6): 1000-1009.

46. Negrin $\mathrm{RS}$, Contag $\mathrm{CH}$ : In vivo imaging using bioluminescence: a tool for probing graft-versus-host disease. Nat Rev Immunol 2006, 6(6):484-490.

47. Rocchetta HL, Boylan CI, Foley JW, Iversen PW, LeTourneau DL, McMillian CL, Contag PR, Jenkins DE, Parr TR Jr: Validation of a noninvasive, real-time imaging technology using bioluminescent Escherichia coli in the neutropenic mouse thigh model of infection. Antimicrob Agents Chemother 200I, 45(I): I29-I 37.

48. Wiles S, Clare S, Harker J, Huett A, Young D, Dougan G, Frankel G: Organ specificity, colonization and clearance dynamics in vivo following oral challenges with the murine pathogen Citrobacter rodentium. Cell Microbiol 2004, 6( I 0):963-972.

49. Yu YA, Timiryasova T, Zhang Q, Beltz R, Szalay AA: Optical imaging: bacteria, viruses, and mammalian cells encoding lightemitting proteins reveal the locations of primary tumors and metastases in animals. Anal Bioanal Chem 2003, 377(6):964-972.

50. Park HS, Francis KP, Yu J, Cleary PP: Membranous cells in nasalassociated lymphoid tissue: a portal of entry for the respiratory mucosal pathogen group A streptococcus. I Immunol 2003, I 7 I(5):2532-2537. 
5I. Malik M, Bakshi CS, Sahay B, Shah A, Lotz SA, Sellati T): Toll-like receptor 2 is required for control of pulmonary infection with Francisella tularensis. Infect Immun 2006, 74(6):3657-3662.

52. Malik M, Bakshi CS, McCabe K, Catlett SV, Shah A, Singh R, Jackson PL, Gaggar A, Metzger DW, Melendez JA, Blalock JE, Sellati TJ: Matrix metalloproteinase 9 activity enhances host susceptibility to pulmonary infection with type $A$ and $B$ strains of Francisella tularensis. J Immunol 2007, I 78(2): I013-1020.

53. KuoLee R, Harris G, Conlan JW, Chen W: Oral immunization of mice with the live vaccine strain (LVS) of Francisella tularensis protects mice against respiratory challenge with virulent type A F. tularensis. Vaccine 2007, 25( 19):378|-379|

54. Heritage PL, Underdown BJ, Arsenault AL, Snider DP, McDermott MR: Comparison of murine nasal-associated lymphoid tissue and Peyer's patches. Am J Respir Crit Care Med I997, I56(4 Pt I): $1256-1262$.

55. Verjans GM, Ringrose JH, van Alphen L, Feltkamp TE, Kusters JG: Entrance and survival of Salmonella typhimurium and Yersinia enterocolitica within human B- and T-cell lines. Infect Immun 1994, 62(6):2229-2235.

56. Vazquez-Torres A, Jones-Carson J, Baumler AJ, Falkow S, Valdivia R, Brown W, Le M, Berggren R, Parks WT, Fang FC: Extraintestinal dissemination of Salmonella by CDI8-expressing phagocytes. Nature 1999, 40 I(6755):804-808.

57. McCathey SN, Shomer NH, Schrenzel MD, Whary MT, Taylor NS, Fox JG: Colonization and tissue tropism of Helicobacter pylori and a novel urease-negative Helicobacter species in ICR mice are independent of route of exposure. Helicobacter 1999, 4(4):249-259.

58. Fedorka-Cray PJ, Kelley LC, Stabel TJ, Gray JT, Laufer JA: Alternate routes of invasion may affect pathogenesis of Salmonella typhimurium in swine. Infect Immun 1995, 63(7):2658-2664.

59. Haristoy $X$, Lozniewski A, Tram C, Simeon D, Bevanger L, Lion $C$ Francisella tularensis bacteremia. J Clin Microbiol 2003, 4 I(6):2774-2776

60. Forestal CA, Malik M, Catlett SV, Savitt AG, Benach JL, Sellati TJ, Furie MB: Francisella tularensis has a significant extracellular phase in infected mice. J Infect Dis 2007, 196(I): I34-137.

61. Chiavolini D, Alroy J, King CA, Jorth P, Weir S, Madico G, Murphy JR, Wetzler LM: Identification of immunologic and pathologic parameters of death versus survival in respiratory tularemia. Infect Immun 2008, 76(2):486-496.

62. Fortier AH, Slayter MV, Ziemba R, Meltzer MS, Nacy CA: Live vaccine strain of Francisella tularensis: infection and immunity in mice. Infect Immun I99|, 59(9):2922-2928.

63. Woolard MD, Hensley LL, Kawula TH, Frelinger JA: Respiratory Francisella tularensis live vaccine strain infection induces Th 17 cells and prostaglandin E2, which inhibits generation of gamma interferon-positive $\mathbf{T}$ cells. Infect Immun 2008 , 76(6):265I-2659.

64. Mahanty S, Gupta M, Paragas J, Bray M, Ahmed R, Rollin PE: Protection from lethal infection is determined by innate immune responses in a mouse model of Ebola virus infection. Virology 2003, $312(2): 415-424$.

65. Liu PT, Stenger S, Li H, Wenzel L, Tan BH, Krutzik SR, Ochoa MT, Schauber J, Wu K, Meinken C, Kamen DL, Wagner M, Bals R, Steinmeyer A, Zugel U, Gallo RL, Eisenberg D, Hewison M, Hollis BW, Adams JS, Bloom BR, Modlin RL: Toll-like receptor triggering of a vitamin D-mediated human antimicrobial response. Science 2006, 3 II I(5768): I770-1773.

66. McSorley SJ, Asch S, Costalonga M, Reinhardt RL, Jenkins MK: Tracking salmonella-specific CD4 $\mathrm{T}$ cells in vivo reveals a local mucosal response to a disseminated infection. Immunity 2002 16(3):365-377.

67. Raz E: Organ-specific regulation of innate immunity. Nat Immunol 2007, 8(I):3-4

68. Zucchini N, Bessou G, Robbins SH, Chasson L, Raper A, Crocker PR, Dalod $M$ : Individual plasmacytoid dendritic cells are major contributors to the production of multiple innate cytokines in an organ-specific manner during viral infection. Int Immunol 2008, 20(I):45-56.

69. Mattner J, Donhauser N, Werner-Felmayer G, Bogdan C: NKT cells mediate organ-specific resistance against Leishmania major infection. Microbes Infect 2006, 8(2):354-362.
70. Metzger DW, Bakshi CS, Kirimanjeswara G: Mucosal immunopathogenesis of Francisella tularensis. Ann N Y Acad Sci 2007, I 1 05:266-283.

71. Mares CA, Ojeda SS, Morris EG, Li Q, Teale JM: Initial delay in the immune response to Francisella is followed by hypercytokinemia characteristic of severe sepsis and correlating with upregulation and release of damage associated molecular patterns (DAMPs). Infect Immun 2008.

72. Adonai N, Nguyen KN, Walsh J, lyer M, Toyokuni T, Phelps ME, McCarthy T, McCarthy DW, Gambhir SS: Ex vivo cell labeling with 64Cu-pyruvaldehyde-bis(N4-methylthiosemicarbazone) for imaging cell trafficking in mice with positron-emission tomography. Proc Natl Acad Sci USA 2002, 99(5):3030-3035.
Publish with Bio Med Central and every scientist can read your work free of charge

"BioMed Central will be the most significant development for disseminating the results of biomedical research in our lifetime. "

Sir Paul Nurse, Cancer Research UK

Your research papers will be:

- available free of charge to the entire biomedical community

- peer reviewed and published immediately upon acceptance

- cited in PubMed and archived on PubMed Central

- yours - you keep the copyright 